\title{
Palaeogeographic implications of a new iocrinid crinoid (Disparida) from the Ordovician (Darriwillian) of Morocco
}

Samuel Zamora, Imran A Rahman, William I Ausich

Complete, articulated crinoids from the Ordovician peri-Gondwanan margin are rare. Here, we describe a new species, locrinus africanus sp. nov., from the Darriwilian-age Taddrist Formation of Morocco.The anatomy of this species was studied using a combination of traditional palaeontological methods and non-destructive X-ray micro-tomography (micro$\mathrm{CT}$ ). This revealed critical features of the column, distal arms, and aboral cup, which were hidden in the surrounding rock and would have been inaccessible without the application of micro-CT. locrinus africanus sp. nov. is characterized by the presence of seven to thirteen tertibrachials, three in-line bifurcations per ray, and an anal sac that is predominantly unplated or very lightly plated. locrinus is a common genus in North America (Laurentia) and has also been reported from the United Kingdom (Avalonia) and Oman (middle east Gondwana). Together with Merocrinus, it represents one of the few geographically widespread crinoids during the Ordovician and serves to demonstrate that faunal exchanges between Laurentia and Gondwana occurred at this time. This study highlights the advantages of using both conventional and cutting-edge techniques (such as micro-CT) to describe the morphology of new fossil specimens. 
1 ${ }_{1}$ Palaeogeographic implications of a new

\section{iocrinid crinoid (Disparida) from the}

\section{${ }_{3}$ Ordovician (Darriwillian) of Morocco}

4

5Samuel Zamora ${ }^{1}$, Imran A. Rahman ${ }^{2}$ and William I. Ausich ${ }^{3}$

6

$7^{1}$ Instituto Geológico y Minero de España, Zaragoza, Spain

$8^{2}$ School of Earth Sciences, University of Bristol, Bristol, UK

$9^{3}$ School of Earth Sciences, The Ohio State University, Columbus, USA

10

11Corresponding Author:

12Samuel Zamora

13Instituto Geológico y Minero de España, C/ Manuel Lasala, 44 - 9 B, 50006 Zaragoza, Spain 14Email address: s.zamora@igme.es 
15ABSTRACT

16Complete, articulated crinoids from the Ordovician peri-Gondwanan margin are rare. Here, we 17describe a new species, Iocrinus africanus sp. nov., from the Darriwilian-age Taddrist Formation 18of Morocco. The anatomy of this species was studied using a combination of traditional 19palaeontological methods and non-destructive X-ray micro-tomography (micro-CT). This 20revealed critical features of the column, distal arms, and aboral cup, which were hidden in the 21surrounding rock and would have been inaccessible without the application of micro-CT. 22Iocrinus africanus sp. nov. is characterized by the presence of seven to thirteen tertibrachials, 23three in-line bifurcations per ray, and an anal sac that is predominantly unplated or very lightly 24plated. Iocrinus is a common genus in North America (Laurentia), and has also been reported 25 from the United Kingdom (Avalonia) and Oman (middle east Gondwana). Together with 26Merocrinus, it represents one of the few geographically widespread crinoids during the 27Ordovician and serves to demonstrate that faunal exchanges between Laurentia and Gondwana 28occurred at this time. This study highlights the advantages of using both conventional and 29cutting-edge techniques (such as micro-CT) to describe the morphology of new fossil specimens. 30

31Subjects: Paleontology, Taxonomy

32Keywords: Echinoderms, Paleozoic, Africa, Merocrinus, Micro-CT, Paleogeography

\section{INTRODUCTION}


36Ordovician crinoids from west peri-Gondwana (North Africa and southwestern and central 37Europe) are relatively rare, with only a few species reported from Spain, France, Italy, Morocco, 38Portugal, and the Czech Republic (Ubaghs, 1969, 1983; Prokop \& Petr, 1999; Ausich, Gil Cid \& 39Domínguez Alonso, 2002; Ausich, Sá \& Gutiérrez-Marco, 2007; Correia \& Loureiro, 2009; 40Zamora, Colmenar \& Ausich, 2014; Sumrall et al., 2015). Crinoids from Morocco include an 41incomplete specimen assigned to Ramseyocrinus sp. by Donovan and Savill (1988) from the 42Upper Fezouata Formation, which is Floian (Early Ordovician) in age (sensu Ausich, Sá \& 43Gutiérrez-Marco, 2007), and several well-preserved complete specimens of Rosfacrinus robustus 44Le Menn and Spjeldnaes, 1996, from the Upper Tiouririne Formation (Lefebvre et al., 2007), 45which is Katian (Late Ordovician).

46 Most of the crinoid genera from the Ordovician of peri-Gondwana are endemic, and this 47hampers our ability to understand the migration patterns of crinoids during this important time 48interval, in which several echinoderm classes reached major peaks in diversity (Guensburg \& 49Sprinkle, 2000; Sprinkle \& Guensburg, 2004; Nardin \& Lefebvre, 2010; Lefebvre et al., 2013). 50Until now, the only exception was Merocrinus, which has been reported from England 51(Avalonia), Spain (peri-Gondwana), and North America (Laurentia) (Ausich, Gil Cid \& 52Domínguez Alonso, 2002). Herein, we report a new species of Iocrinus from the Ordovician of 53Morocco, thereby extending the range of this genus with certainty to encompass west peri54Gondwana (in addition to Avalonia and Laurentia; Donovan et al., 2011) and confirming its 55cosmopolitan distribution. Iocrinus africanus sp. nov. is described based on a single well56preserved specimen, which was collected from south Alnif (eastern Anti-Atlas, Morocco) and is 57preserved in a concretion found in the Taddrist Formation, which is Darriwilian in age (Rábano, 58Gutiérrez-Marco \& García-Bellido, 2014). The new crinoid was studied using both traditional 
59techniques (casting the mould in latex) and X-ray micro-tomography (micro-CT). This allows us 60to describe the morphology of Iocrinus africanus sp. nov. in great detail and serves as a basis for 61comparison with other species of Iocrinus.

62

\section{Geological Setting and Stratigraphy}

64Ordovician outcrops are very well developed and exposed in the Anti-Atlas Mountains of 65Morocco (Destombes, Hollard \& Willefert, 1985). Many units yield well-preserved specimens 66of echinoderms, a number of which are currently under study (e.g., Hunter et al., 2010; Van 67Roy et al., 2010, 2015; Sumrall \& Zamora, 2011; Martin et al., in press), and these faunas 680ccur throughout sections from the Lower to Upper Ordovician. Numerous clades of 69echinoderms have been documented, including stylophorans, solutes, blastozoans, crinoids, 70asteroids, edrioasteroids, and cyclocystoids.

71 The Ordovician succession in the Anti-Atlas region is divided into the following 72lithostratigraphic units: the Outer Feijas Shale Group, the First Bani Sandstone Group, the 73Ktaoua Clay and Sandstone Group, and the Second Bani Sandstone Group (Choubert, 1943; 74Choubert \& Termier, 1947; Destombes, Hollard \& Willefert, 1985). The Outer Feijas Shale 75Group includes the Lower and Upper Fezouta formations (Tremadocian-Floian) and the 76Tachilla Formation (Darriwilian) (Fig. 1). These units are characterized by siltstones that are 77rich in graptolites, with some thin sandstone interbeds, and contain exceptionally preserved 78Burgess Shale-type faunas in places (Van Roy et al., 2010, 2015; Martin et al., in press). The 79overlying First Bani Group spans the Darriwilian to Sandbian and is subdivided into five 8oformations (Taddrist, Bou-Zeroual, Guezzart, Ouine-Inirne, and Izegguirene formations) that 81are chiefly comprised of sandstones with interbedded shales. This group is the thickest, most 
82constant, and most extensive sandstone group in the Anti-Atlas Mountains (Destombes, 83Hollard \& Willefert, 1985). The fossil taxa recovered from the First Bani Group were 84reviewed by Gutiérrez-Marco et al. (2003), and there are no reports of crinoids from this time 85interval.

86 The First Bani Group is overlain by the Ktaoua Clay and Sandstone Group (Sandbian87Katian), which is comprised of siltstones interbedded with two or three sandstone units, 88depending on the exact position within the Anti-Atlas Mountains. It is divided into three units: 89the Sandbian to Katian Lower Ktaoua Formation, the Katian Upper Tiouririne Formation, and 90the Katian Upper Ktaoua Formation. The Ordovician ends with the Second Bani group, which 91is Hirnantian in age.

92 The new locality yielding Iocrinus africanus sp. nov. lies in the Taddrist Formation, low in 93the First Bani Group, close to the village of Battou (south Alnif, eastern Anti-Atlas) (Figs. 1, 2). 94This locality was recently described by Rábano, Gutiérrez-Marco, and García-Bellido (2014), 95who provided detailed information about the faunal content and age based on the presence of key 96graptolites and trilobites. In this area, the Taddrist Formation has been excavated predominantly 97by local collectors and has yielded a rich faunal assemblage preserved in carbonate concretions 98(Fig. 3). Rábano, Gutiérrez-Marco, and García-Bellido (2014) suggested that the levels 99containing fossiliferous concretions belong to the Didymograptus murchisoni Biozone 100(Gutiérrez-Marco et al., 2003), which is assigned to the upper Oretanian, a regional stage 101roughly equivalent to the upper Darriwilian 2/basal Darriwilian 3 stage slices of the global 102chronostratigraphic scale (Gutiérrez-Marco, Sá \& Rábano, 2008; Bergström et al., 2009). 103According to Rábano, Gutiérrez-Marco, and García-Bellido (2014), the fossiliferous concretions 104have yielded the trilobites Caudillaenus nicolasi Rábano, Gutiérrez-Marco, and García-Bellido, 
1052014, Morgatia? rochi (Destombes, 1972), Placoparia (Coplacoparia) sp. nov., Colpocoryphe 106sp., Parabarrandia aff. crassa (Barrande, 1872), and an undetermined cheirurid (Eccoptochile? 107sp.). Other non-trilobite fossils include molluscs (e.g., a cyrtonellid tergomyan, bivalves such as 108 Praenucula sp., and orthoconicnautiloids), hyoliths (Elegantilites sp.), echinoderms (Diploporita 109and Asterozoa indet.), conularids (Exoconularia sp.), and rare graptolites (Didymograptus sp.). 110In addition to the crinoid described herein, new cyclocystoids, the first ever reported from Africa, 111were recently presented from this locality and await formal description (Sprinkle, Reich \& 112Lefebvre, 2015).

113

114

\section{MATERIAL AND METHODS}

116The studied specimen is preserved in a yellowish carbonate concretion that is approximately 70 $117 \mathrm{~mm}$ in length and $45 \mathrm{~mm}$ in width. The crinoid is preserved as a natural mould and includes the 118complete theca, articulated arms, and part of the column. The specimen is housed in the Museo 119Geominero (Madrid, Spain) under the repository number MGM 6754.

120 A latex cast of the specimen was prepared to study the morphology of the animal (Fig. 4). 121In addition, the specimen was imaged using micro-CT and digitally reconstructed to characterize 122the fossil in three dimensions (Fig. 5). The specimen was scanned on a Nikon XT H 225 cabinet 123scanner at the Natural History Museum, London with a $0.5 \mathrm{~mm}$ thick copper filter, $215 \mathrm{kV}$ 124voltage, $177 \mu \mathrm{A}$ current, and 3142 projections (each with an exposure time of $708 \mathrm{~ms}$ ). 125Tomographic reconstruction was performed in Nikon CT Pro software using filtered back 126projection, giving a tomographic dataset with a voxel size of $37 \mu \mathrm{m}$. This dataset was then 127visualized with the free SPIERS software suite (Sutton et al., 2012); an inverted linear threshold 
128was applied to the dataset, and the pixels that could be unambiguously identified as representing 129the crinoid were manually assigned to a separate region-of-interest. Isosurfaces were rendered to 130give an interactive three-dimensional model of the fossil, which was subjected to weak 131smoothing and island removal to reduce noise. Micro-CT slices, segmented images, and the 132interactive 3-D model (in VAXML format) are provided as supplemental information 133(http://dx.doi.org/10.5523/bris.uv7qt4c6kpat1befj0937ooml).

134

\section{Terminology}

136The terminology used below follows Moore (1962), Webster (1974), Ubaghs (1978), and Ausich 137et al. (1999); the classification follows Ausich (1998). Note, the terminology used for the aboral 138plates differs from that of Ausich, Gil Cid, and Domínguez Alonso (2002). In addition, 139superradial and inferradial are used to designate radially positioned plates where two plates are in 140the $\mathrm{C}$ ray portion of the radial circlet. This usage recognizes the homologies of these plates 141(essential for phylogenetic analysis) rather than using unique names that obscure homology, such 142as anibrachial and brachianal as outlined in Ubaghs (1978). The present usage is consistent with 143many recent studies (e.g., Ausich, 1998; Ausich and Copper, 2010; Ausich et al., 2015a, 2015b), 144although the Ubaghs (1978) terminology for these plate is also used (e.g., Guensburg, 2010).

\section{Nomenclatural acts}

147The electronic version of this article in Portable Document Format (PDF) will represent a 148published work according to the International Commission on Zoological Nomenclature (ICZN), 149and hence the new names contained in the electronic version are effectively published under that 150Code from the electronic edition alone. This published work and the nomenclatural acts it 
8

151contains have been registered in ZooBank, the online registration system for the ICZN. The 152ZooBank LSIDs (Life Science Identifiers) can be resolved and the associated information viewed 153through any standard web browser by appending the LSID to the prefix http://zoobank.org/. The 154LSID for this publication is: urn:lsid:zoobank.org:act:D091338E-643F-4D5A-8A08-

1557D7D190DBC2E. The online version of this work is archived and available from the following 156digital repositories: PeerJ, PubMed Central and CLOCKSS.

157

158

159RESULTS

160Systematic paleontology

161 Class CRINOIDEA Miller, 1821

162 Subclass DISPARIDA Moore and Laudon, 1943

163 Order MYELODACTYLIDA Ausich, 1998

164 Family IOCRINIDAE Moore and Laudon, 1943

165 Genus Iocrinus Hall, 1866

166

167Type species

168Heterocrinus (Iocrinus) polyxo Hall, 1866 = Heterocrinus subcrassus Meek and Worthen, 1865. . 169

170Diagnosis

171Iocrinid with basal plates visible in lateral view; anal sac with large plicate plates if calcified; 172variable number of primibrachials; arms branch as many as eight times; fixed interradial plates 
173absent; column holomeric, pentalobate throughout; columnal facets in mesistele petaloid.

174

175 Iocrinus africanus sp. nov. urn:1sid:zoobank.org:act:D091338E-643F-4D5A-8A08-

176

7D7D190DBC2E

177

178Holotype

179MGM 6754, a nearly complete, articulated specimen not retaining the attachment structure and 180dististele preserved as a mould in a carbonate concretion (Figs. 4, 5; Data S1, S2).

181

182Type locality and age

183Close to the village of Battou, south Alnif, eastern Anti-Atlas, Morocco (Fig. 2); Taddrist 184Formation, Darriwilian (Middle Ordovician).

185

186Etymology

187Named in reference to the African continent.

188

189Diagnosis

190Basal plate height approximately 37 percent of radial plate height; radial plates 1.25 times higher 191than wide; single, broad transverse ridge between adjacent radial plates; primibrachials 1.5 times 192wider than high; three to five primibrachials; four to five secundibrachials; seven to thirteen 193tertibrachials; three in-line bifurcations per ray; anal sac unplated or very lightly plated (except 194for the robust column of plates from the C-ray superradial); proximal columnals pentastellate. 195 
196Description

197Crown small in size. Aboral cup medium bowl-shaped; smooth plate surfaces; radial and basal 198plates sharply convex.

199 Basal circlet 27 percent of aboral cup height; five basal plates, approximately two times 200wider than high, much smaller than radial plates. Radial circlet 73 percent of aboral cup height; 201radial plates five, maximum height approximately 1.25 times higher than maximum width; 202maximum width of radial plate at mid-height, radials narrow sharply proximally, maximum 203width more than 10 times proximal width; maximum width 1.6 times distal width. Radial facets 204peneplenary, approximately as deep as wide. A, B, D, E radial plates simple, C radial compound; 205C inferradial approximately same size as simple radials; C superradial much smaller than C 206inferradial, wider than high, distal heterotomous division with anal plates to left and C-ray arm to 207right.

208 All anal plates above aboral cup; column of 16 stout anal sac plates preserved from the left 209facet on the C-ray superradial, plates very convex, successive plates with bend yielding a sinuous 210appearance for this column of plates; each plate higher than wide, otherwise very similar to 211shape of brachials. Other anal sac plates disarticulated and collapsed within the crown, 212presumably sac plates were lightly calcified or uncalcified, except for the column of plates from 213the C superradial.

214 Arms robust, primaxil varies from third to fifth primibrachial (45553; ABCDE), secundaxil 215 fourth or fifth secundibrachial; where known, tertaxil positioned on the seventh or thirteenth 216tertibrachial; as many as 16 unbranched quartibrachials on an incomplete branch of the A-ray 217arm. Brachials strongly convex aborally with flattened lateral, abambulacral extensions, 218rectangular uniserial, deep ambulcacral groove, more proximal brachials approximately 1.7 times 
219wider than high. Brachial facet with two, merging aboral ligament fossae. Primaxial 220approximately the same size as non-axillary primibrachials; remaining brachials diminish in size 221distally.

222 Column strongly pentastellate, holomeric, heteromorphic, proximal column N3231323; 223nodals higher than priminternodals, obvious heteromorphic pattern lacking in mesistele, large 224portion of columnal facets presumably a petaloid articulation (but details not preserved). 225Preserved column higher than crown height and preserved in an open coil.

\section{Remarks}

228Characters differentiating genera within the Iocrinidae are listed in Ausich, Rozhnov, and 229Kammer (2015). The combination of visible basal plates, three to five primibrachials, no fixed 230interradial plates, pentalobate/pentastellate columnal shape, holomeric column construction, and 231a petaloid facet clearly align the new crinoid described herein with the genus Iocrinus. Another 232feature that identifies the specimen as belonging to Iocrinus is the preservation of the column in 233an open coil. This is similar to Iocrinus subcrassus, which is thought to have had a holdfast that 234could coil around erect objects (Kelly, 1978; Brett, Deline \& McLaughlin, 2008; Meyer \& Davis, 2352009).

236 Species-level characters within Iocrinus include: the height of the basal plates, the height 237of the radial plates, radial plate height versus width, presence and character of the transverse 238ridge between adjacent radial plates, primibrachial shape, number of primibrachials, number of 239secundibrachials, number of tertibrachials, maximum number of in-line bifurcations in a ray, anal 240sac plating, and the shape of the proximal columnal (Table 1). Iocrinus africanus sp. nov. is 241distinguished from other Iocrinus species based on the shape of the radial plates, the number of 
242tertibrachials, the number of bifurcations in-line per ray, and the lack of or very light plating of 243most of the anal sac.

244 Donovan et al. (2011) reported the only other putative Iocrinus known from Gondwana, $I$. 245sp. cf. I. subcrassus from the Middle Ordovician of Oman. Assuming that this taxon does belong 246to Iocrinus, which cannot be confirmed without further information about the CD-interray and C247ray morphologies, the new Moroccan species differs from the Donovan et al. (2011) specimen as 248follows. Iocrinus africanus sp. nov. has a basal plate height approximately 37 percent of radial 249plate height; a broad transverse ridge; primibrachials 1.5 times wider than high; four to five 250secundibrachials; and three in-line bifurcations per ray. In contrast, I. sp. cf. I. subcrassus has a 251basal plate height approximately 50 percent of radial plate height; a narrow transverse ridge; 252primibrachials slightly higher than wide; seven secundibrachials; and as many as seven in-line 253bifurcations per ray.

254 Taxonomic assignments within the Iocrinidae have received some attention in the last three 255decades (Warn, 1982; Guensburg, 1984; Donovan, 1985, 1989; Ausich, Rozhnov \& Kammer, 2562015); with the new species described herein, a total of eight species and one subspecies are 257currently recognized for Iocrinus (Webster \& Webster, 2014). These include the Laurentian 258species: I. crassus (Meek and Worthen, 1865); I. similis (Billings, 1865); I. subcrassus (Meek 259and Worthen, 1865); I. subcrassus torontoensis Fritz, 1925; and I. trentonensis Walcott, 1884; 260and the Avalonian species: I. llandegleyi Botting, 2003; I. pauli Donovan and Gale, 1989; and I. 261whitteryi Ramsbottom, 1961 (Table 2). Additional Iocrinus identifications left in open 262nomenclature are known from Avalonia, Laurentia, and Gondwana (for the previous potential 263Gondwanan occurrence, see Donovan et al., 2011). Iocrinus africanus sp. nov. is Darriwilian in 264age, and thus it is among the oldest members of the genus (Table 2). In terms of morphology, it is 
265equally dissimilar to species from both Laurentia and Avalonia. The occurrence of I. africanus 266sp. nov. in Morocco confirms the presence of Iocrinus in Gondwana and demonstrates that 267Iocrinus, together with Merocrinus, is the most geographically widespread Ordovician crinoid 268genus.

269 The use of micro-CT was essential for describing the morphology of Iocrinus africanus sp. 270nov. in full. The posterior interray is buried below the surface of the concretion and is hence not 271visible in the latex casts (Fig. 4); however, the posterior interray and the C-ray can be clearly 272seen in the micro-CT scans (Fig. 5; Data S1, S2). Without an understanding of these characters, it 273would not have been possible to confidently assign the specimen to the genus Iocrinus.

274

275

\section{PALEOBIOGEOGRAPHICAL IMPLICATIONS}

277The Middle to Late Ordovician was characterized by high degrees of endemism in crinoids 278(Paul, 1976; Lefebvre et al., 2013), and Iocrinus and Merocrinus are the only geographically 279widespread genera from this period (Fig. 6). Both genera first appeared in Gondwana and/or 280Avalonia during the Darriwillian. Merocrinus first occurred in Laurentia during the Sandbian, 281and Iocrinus first occurred in Laurentia during the Katian (however, Sprinkle et al., 2008, noted 282the occurrence of older, undescribed iocrinids and a merocrinid-like cladid? from faunas in North 283America). Based on presently described taxa, the known geographical distribution of these 284genera indicates that their migration to Laurentia was asynchronous. Iocrinus is a disparid 285crinoid, and disparids are usually recognized as having a more widespread geographic 286distribution and temporal range than other clades (Kammer et al., 1998). Merocrinus is generally 287considered to be a cladid (but see Sprinkle and Guensburg, 2013), which in general are not as 
288cosmopolitan as disparids, at least later during the Paleozoic. Unfortunately, there is not currently 289enough known about the life history of Paleozoic crinoids to propose any explanation for the 290cosmopolitan nature of Iocrinus and Merocrinus during the Ordovician.

291

292

\section{ACKNOWLEDGEMENTS}

294We appreciate the comments of four reviewers, Christian Klug (University of Zurich), Stephen 295Donovan (Naturalis Biodiversity Center), James Sprinkle (University of Texas at Austin) and 296Forest Gahn (Brigham Young University), which greatly improved the final manuscript. We 297thank Isabel Pérez (University of Zaragoza) for providing photographs of the studied specimen 298and Dan Sykes (Natural History Museum, London) for assistance with micro-CT. The specimen 299was collected by Samuel Zamora on a field trip accompanied by Andrew Smith (Natural History 300Museum, London). Juan Carlos Gutiérrez-Marco (Spanish Research Council) and Richard Fortey 301(Natural History Museum, London) provided helpful comments on the associated fauna, and 302Bertrand Lefebvre (University of Lyon) is thanked for important discussions on echinoderms 303from Morocco.

304

305

306ADDITIONAL INFORMATION AND DECLARATIONS

307Competing Interests

308 No competing interests. 
310Author Contributions

311 Samuel Zamora collected the holotype specimen, conceived and designed the experiments,

312 analyzed the data, wrote the paper, prepared figures/tables, reviewed drafts of the paper.

313 Imran Rahman performed the experiments, analyzed the data, wrote the paper, prepared

314 figures/tables, reviewed drafts of the paper.

315 William Ausich analyzed the data, wrote the paper, prepared figures/tables, reviewed drafts

316 of the paper.

317

318Supplemental Information

319Supplemental information for this article can be found online at the following link:

320http://dx.doi.org/10.5523/bris.uv7qt4c6kpat1befj0937ooml

321

322REFERENCES

323Ausich WI. 1998. Early phylogeny and subclass division of the Crinoidea (phylum

324 Echinodermata). Journal of Paleontology 72:499-510.

325Ausich W, Copper P. 2010. The Crinoidea of Anticosti Island, Québec (Late Ordovician to

326 Early Silurian). Palaeontographica Canadiana, 29:1-157.

327Ausich WI, Brett CE, Hess H, Simms MJ. 1999. Crinoid form and function. In: Hess H,

328 Ausich WI, Brett CE, Simms MJ, eds. Fossil crinoids. Cambridge: Cambridge University

329 Press. 3-30.

330Ausich WI, Gil Cid MD, Domínguez Alonso P. 2002. Ordovician [Dobrotivian (Llandeilian

331 Stage) to Ashgill] crinoids (phylum Echinodermata) from the Montes de Toledo and Sierra

332 Morena, Spain with implications for the paleogeography of Peri-Gondwana. Journal of 
333 Paleontology 76:975-992.

3341Ausich WI, Kammer TW, Rhenberg EC, Wright DF. 2015a. Early phylogeny of crinoids

335 within the pelmatozoan clade. Palaeontology [published online 5 Oct 2015; doi:

336 10.1111/pala.12204].

3372Ausich WI, Rozhnov SV, Kammer TW. 2015b. Iocrinid crinoids from the Ordovician of the

338 Baltic Region, Estonia. Paleontological Journal 49:145-152.

339Ausich WI, Sá AA, Gutiérrez-Marco JC. 2007. New and revised occurrences of Ordovician

340 crinoids from southwestern Europe. Journal of Paleontology 81:1374-1383.

341Barrande J. 1872. Systême silurien du centre de la Bohême. lère partie: Recherches

342 paléontologiques. Supplément au Vol. I. Trilobites, crustacés divers et poissons. 647 pp. Chez

343 l'auteur et éditeur, Imprimerie de Charles Bellmann, Prague.

344Bergström SM, Chen X, Gutiérrez-Marco JC, Dronov AV. 2009. The new chronostratigraphic

345 classification of the Ordovician System and its relations to major regional series and stages

346 and $\delta^{13} \mathrm{C}$ chemostratigraphy. Lethaia 42:97-107.

347Billings E. 1865. Paleozoic fossils (from Silurian). Geological Society of Canada 1:1-426.

348Botting JP. 2003. Llanvirn (Middle Ordovician) echinoderms from Llandegley rocks, central

349 Wales. Palaeontology 46:685-708.

350Brett CE, Deline BL, McLaughlin PI. 2008. Attachment, facies distribution, and life history

351 strategies in crinoids from the Upper Ordovician of Kentucky. In: Ausich WI, Webster GD,

352 eds. Echinoderm paleobiology. Bloomington: Indiana University Press. 23-52.

353Choubert G. 1943. L'Acadien et l'Ordovicien de l'Anti Atlas. Comptes Rendus Adadémie

354 Sciences Paris 216:1092-1094.

355Choubert G, Termier H. 1947. Sur la stratigraphie de l'Ordovicien marocain. Comptes 
356 Rendus sommaire Société géologique France 16:335-337.

357Cocks LRM, Torsvik TH. 2006. European geography in a global context from the Vendian to 358 the end of the Palaeozoic. In: Gee DG, Stephenson RA, eds. European lithosphere 359 dynamics. Geological Society, London, Memoirs 32:83-95.

360Correia P, Loureiro J. 2009. Novas ocorrências de crinóides no Darriwiliano (Ordovícico 361 Médio) do anticlinal de Valongo (NW de Portugal). Paleolusitana 1:141-150.

362Destombes J. 1972. Les trilobites du sous-ordre des Phacopina de l'Ordovicien de l'Anti-Atlas 363 (Maroc). Notes et Mémoires du Service Géologique du Maroc 240: 1-114.

364Destombes J, Hollard H, Willefert S. 1985. Lower Palaeozoic rocks of Morocco. In Holland $365 \mathrm{CH}$, ed. Lower Palaeozoic rocks of the world. Vol. 4. Lower Palaeozoic rocks of Northwest 366 and West-Central Africa. Chichester: John Wiley and Sons. 91-336.

367Donovan SK. 1985. The Ordovician crinoid genus Caleidocrinus Waagen and Jahn, 1899. 368 Geological Journal 20:109-121.

369Donovan SK. 1989. Pelmatozoan columnals from the Ordovician of the British Isles. Part 2. 370 Monographs of the Palaeontographical Society, London 142 (580):69-114 371Donovan SK, Gale AS. 1989. Iocrinus in the Ordovician of England and Wales. Palaeontology $372 \quad 32: 313-323$.

373Donovan SK, Savill JJ. 1988. Ramseyocrinus (Crinoidea) from the Arenig of Morocco. Journal 374 of Paleontology 62:283-285.

375Donovan SK, Miller CG, Sansom IJ, Heward AP, Schreurs J. 2011. A Laurentian Iocrinus 376 Hall (Crinoidea, Disparida) in the Dapingian or Darriwilian (Middle Ordovician, Arenig) of 377 Oman. Palaeontology 54:525-533.

378Fortey RA, Harper DAT, Ingham JK, Owen AW, Rushton AWA. 1995. A revision of 
379 Ordovician series and stages from the historical type area. Geological Magazine 132:15-

380 30.

381Fritz MA. 1925. The stratigraphy and paleontology of Toronto and vicinity, Part IV; Hydrozoa, 382 Echinodermata, Trilobita, and markings. Ontario Department of Mines, Annual Report 32:138334.

384Guensburg TE. 1984. Echinodermata of the Middle Ordovician Lebanon Limestone, central 385 Tennessee. Bulletins of American Paleontology 86:1-100.

386Guensburg TE. 2010. Alphacrinus new genus and origin of the disparid clade. Journal of 387 Paleontology 84:1209-1216.

388 Guensburg TE, Sprinkle J. 2000. Ecologic radiation of Cambro-Ordovician echinoderms. In: 389 Zhuravlev AY, Riding R, eds. Ecology of the Cambrian radiation. New York: Columbia 390 University Press. 428-444.

391 Gutiérrez-Marco JC, Destombes J, Rábano I, Aceñolaza GF, Sarmiento GN, San José

392 MA. 2003. El Ordovícico Medio del Anti-Atlas marroquí: paleobiodiversidad, 393 actualización bioestratigráfica y correlación. Geobios 36:151-177.

394Gutiérrez-Marco JC, Sá AA, Rábano I. 2008. Ordovician time scale in Iberia: Mediterranean 395 and global correlation. In: Rozhnov SV, ed. Development of Early Paleozoic biodiversity: role 396 of biotic and abiotic factors, and event correlation. Moscow: KMK Scientific Press. 46-49. 397Hall J. 1866. Descriptions of some new species of Crinoidea and other fossils from the Lower 398 Silurian strata of the age of the Hudson-River Group and Trenton Limestone. Albany: State 399 Cabinet Report. 1-17.

400Hunter AW, Lefebvre B, Nardin E, Régnault S, Van Roy P, Zamora S. 2010. Preliminary 401 report on new echinoderm Lagerstätten from the Upper Ordovician of the eastern Anti-Atlas, 
402 Morocco. In: Harris LG, Boetger SA, Walker CW, Lesser MP, eds. Echinoderms: Durham. 403 London: Taylor \& Francis Group. 23-30.

4043Kammer TW, Baumiller TK, Ausich WI. 1998. Evolutionary significance of differential 405 species longevity in Osagean-Meramecian (Mississippian) crinoid clades. Paleobiology $406 \quad 24: 155-176$.

407Kelly SM. 1978. Functional morphology and evolution of Iocrinus, an Ordovician disparid 408 inadunate crinoid. Unpublished M.S. thesis, Indiana University, Bloomington, 1-80.

409Lefebvre B, Nardin E, Hunter AW, Régnault S. 2007. Les échinodermes de l'Ordovicien 410 supérior de l'Anti-Atlas (Maroc): biostratigraphie et paléobiodiversité. Africa Geoscience 411 Review 14:123-148.

412Lefebvre B, Sumrall CD, Shroat-Lewis RA, Reich M, Webster GD, Hunter AW, Nardin E, 413 Rozhnov SV, Guensburg TE, Touzeau A, Noailles F, Sprinkle, J. 2013.

414 Palaeobiogeography of Ordovician echinoderms. In: Harper DAT, Servais T, eds. Early 415 Palaeozoic biogeography and palaeogeography. Geological Society, London, Memoirs $416 \quad 38: 173-198$.

417Le Menn J, Spjeldnaes N. 1996. Un nouveau crinoïde Dimerocrinitidae (Camerata, 418 Diplobathrida) de l'Ordovicien supérieur du Maroc: Rosfacrinus robustus nov. gen., nov. sp. 419 Geobios 29:341-351. 420Martin ELO, Pittet B, Gutiérrez-Marco JC, Vannier J, El Hariri K, Lerosey-Aubril R, 421 Masrour M, Nowak H, Servais T, Vandenbroucke TRA, Van Roy P, Vaucher R, Lefebvre 422 B. In press. The Lower Ordovician Fezouata Konservat-Lagerstätte from Morocco: age, 423 environment and evolutionary perspectives. Gondwana Research.

424Meek FB, Worthen AH. 1865. Descriptions of new species of Crinoidea, etc., from the 
425 Paleozoic rocks of Illinois and some of the adjoining states. Proceedings of the Academy of 426 Natural Sciences of Philadelphia 17:143-155.

427Meyer DL, Davis RA. 2009. A sea without fish. Life in the Ordovician sea of the Cincinnati 428 region. Bloomington: Indiana University Press. 347 pp.

429Miller JS. 1821. A natural history of the Crinoidea or lily-shaped animals; with observations on 430 the genera Asteria, Euryale, Comatula and Marsupites. Bristol: Bryan and Co. City Printing 431 Office. $150 \mathrm{pp}$.

432Moore RC. 1962. Ray structures of some inadunate crinoids. The University of Kansas 433 Paleontological Contributions, Echinodermata, Article 5:1-47.

434Moore RC, Laudon LR. 1943. Evolution and classification of Paleozoic crinoids. Geological 435 Society of America Special Papers 46:1-158.

436Nardin E, Lefebvre B. 2010. Unravelling extrinsic and intrinsic factors of the early Palaeozoic 437 diversification of blastozoan echinoderms. Palaeogeography, Palaeoclimatology, 438 Palaeoecology 294:142-160.

439Paul, CRC. 1976. Palaeogeography of primitive echinoderms in the Ordovician. In: Bassett MG, 440 ed. The Ordovician system: proceedings of a palaeontological association symposium, 441 Birmingham, September 1974. Cardiff: University of Wales Press. 553-574. 442Prokop RJ, Petr V. 1999. Echinoderms in the Bohemian Ordovician. Journal of the Czech 443 Geological Society 44:63-68.

444Rábano I, Gutiérrez-Marco JC, García-Bellido DC. 2014. A remarkable illaenid trilobite from 445 the Middle Ordovician of Morocco. Bulletin of Geosciences 89:365-374.

446Ramsbottom WHC. 1961. The British Ordovician Crinoidea. Monograph of the 447 Palaeontographical Society 114 (492):1-37. 
448Sprinkle J, Guensburg TE. 2004. Crinozoan, blastozoan, echinozoan, asterozoan, and 449 homalozoan echinoderms. In: Webby BD, Paris F, Droser ML, Percival IG, eds. The great 450 Ordovician biodiversification event. New York: Columbia University Press. 266-280. 451Sprinkle J, Guensburg TE. 2013. Multiple crossovers between monocyclic and dicyclic cup 452 designs: experimentation and plasticity in early crinoid phylogeny. Geological Society of 453 America Abstracts with Programs, 46:138.

454Sprinkle J, Guensburg TE, Gahn FJ. 2008. Overview of Early Ordovician crinoid diversity 455 from the western and southwestern United States. In: Ausich WI, Webster GW, eds. 456 Echinderm Paleobiology. Bloomington: Indiana University Press. 312-328.

458Sprinkle J, Reich M, Lefebvre B. 2015. Computed tomography (CT) scans of a new 459 Ordovician cyclocystoid from Morocco and its orientation and life mode. In: Zamora S, 460 Rábano I, eds. Progress in echinoderm palaeobiology. Cuadernos del Museo Geominero $461 \quad 19: 163-167$.

462Sumrall CD, Zamora S. 2011. Ordovician edrioasteroids from Morocco: faunal exchanges 463 across the Rheic Ocean. Journal of Systematic Palaeontology 9:425-454.

464Sumrall CD, Deline B, Colmenar J, Sheffield S, Zamora S. 2015. New data on late 465 Ordovician (Katian) echinoderms from Sardinia, Italy. In: Zamora S, Rábano I, eds. Progress 466 in echinoderm palaeobiology. Cuadernos del Museo Geominero 19:175-180.

467Sutton MD, Garwood RJ, Siveter DJ, Siveter DJ. 2012. SPIERS and VAXML; a software 468 toolkit for tomographic visualisation and a format for virtual specimen interchange. 469 Paleontologia Electronica 15:1-14. 
470Ubaghs G. 1969. Aethocrinus moorei Ubaghs, n. gen., n. sp., le plus ancient crinoïde dicyclique 471 connu. The University of Kansas Paleontological Contributions 38:1-25.

472Ubaghs G. 1978. Skeletal morphology of fossil crinoids. In: Moore RC, Teichert K., eds.

473 Treatise on invertebrate paleontology, part T, Echinodermata 2. Boulder and Lawrence:

474 Geological Society of America and University of Kansas. T58-T216.

475Ubaghs G. 1983. Echinodermata. Notes sur les échinoderms de l’Ordovicien inférieur de la

476 Montagene Noire (France). In: Courtessole R, Marek L, Pillet J, Ubaghs G, Vizcaïno D, eds.

477 Calymenina, Echinodermata et Hyolitha de l'Ordovicien inférieur de la Montagne Noire

478 (France méridionale). Carcassonne: Mémoires de la Société d'études scientifiques de l'Aude. $479 \quad 33-55$.

480Van Roy P, Orr PJ, Botting JP, Muir LA, Vinther J, Lefebvre B, El Hariri K, Briggs DEG. 481 2010. Ordovician faunas of Burgess Shale type. Nature 465:215-218.

482Van Roy P, Briggs DEG, Gaines RR. 2015. The Fezouata fossils of Morocco; an extraordinary 483 record of marine life in the Early Ordovician. Journal of the Geological Society 172:541-549. 484Villas E, Vizcaïno D, Álvaro JJ, Destombes J, Vennin E. 2006. Biostratigraphic control of 485 the latest-Ordovician glaciogenic unconformity in Alnif (Eastern Anti-Atlas, Morocco), 486 based on brachiopods. Geobios 39:727-737.

487Walcott CD. 1884. Descriptions of new species of fossils from the Trenton Group of New York. 488 New York State Museum of Natural History, Annual Report 35:207-214.

489Warn JM. 1982. Long-armed disparid inadunates. In: Sprinkle J, ed. Echinoderm faunas from 490 the Bromide Formation (Middle Ordovician) of Oklahoma. University of Kansas 491 Paleontological Contributions, Monograph 1:77-89.

492Webby BD, Cooper RA, Bergström SM, Paris F. 2004. Stratigraphic framework and time 
493 slices. In: Webby BD, Paris F, Droser ML, Percival IG, eds. The great Ordovician

494 biodiversification event. New York: Columbia University Press. 41-47.

495Webster GD. 1974. Crinoid pluricolumnal noditaxis patterns. Journal of Paleontology 48:12834961288.

497Webster GD, Webster DW. 2014. Bibliography and index of Paleozoic crinoids, coronates, and 498 hemistreptocrinoids, 1758-2012. http://crinoids.azurewebsites.net/ [April 2015]

499Zamora S, Colmenar J, Ausich WI. 2014. The echinoderm faunas from the Fombuena 500 Formation (Upper Ordovician, Iberian Chains, Spain). In: Royo-Torres R, Verdú FJ, Alcalá L, 501 eds. XXX Jornadas de Paleontología de la Sociedad Española de Paleontología.

502 iFundamental! 24:257-259.

503

504FIGURE CAPTIONS

505Figure 1. Chronostratigraphical chart for the Ordovician, indicating the levels that provided the 506studied specimen. Correlations between stratigraphical units in the Anti-Atlas (after Destombes, 507Hollard \& Willefert, 1985; Gutiérrez-Marco et al., 2003; Villas et al., 2006), the British regional 508time scale (Fortey et al., 1995), North American graptolite zonal sequences (Webby et al., 2004), 509Mediterranean regional stages (Gutierrez-Marco et al., 2003), and global stages are shown. 510Modified from Sumrall and Zamora (2011). Abbreviations: Kral., Kralodvorian; pars., partial; 511Tr., Tremadocian.

512

513Figure 2. Geographical and geological setting of the eastern Anti-Atlas Mountains, Morocco, 514showing the type locality of the new species (indicated by a star) close to the village of Battou. 515After Rábano et al. (2014). A. Map of Africa. B. Detailed map of west Africa showing the 
516position of the Anti-Atlas Mountains. C. Simplified geological map of Morocco with the position 517of the studied locality; a: Precambrian and Palaeozoic rocks, b: Ordovician rocks, c: post518Palaeozoic cover. D. Geographic map indicating the position of the studied locality. 519

520Figure 3. Field photographs showing the Taddrist Formation and the levels yielding fossiliferous 521concretions. A. General view of the Taddrist Formation in the studied area. B. Detail of the 522trench providing the fossiliferous concretions.

523

524Figure 4. Iocrinus africanus sp. nov. (MGM 6754) from the Darriwilian (Middle Ordovician) of 525Morocco. A, B. General morphology including the complete crown showing the E-ray (A) and 526BC-interray (B), the proximal column, and part of the arms. C. Detail of the cup showing the E527ray. D. Detail of the cup showing the A-ray. E. Detail of the cup showing the D-ray. All images 528are photographs of latex casts of the specimen whitened with ammonium chloride sublimate. 529

530Figure 5. Iocrinus africanus sp. nov. (MGM 6754) from the Darriwilian (Middle Ordovician) of 531Morocco. Digital reconstructions of the specimen. A. General morphology showing the AE532interray. B. Detail of the theca showing the C-ray. C. Detail of the cup showing the BC-interray. 533D. Detail of the cup showing the D-ray. E. Detail of the column showing pentastellate shape and 534holomeric construction. F. Detail of the proximal arms showing the E-ray. G. Column in an open 535coil. Abbreviations: A-E, ambulacra.

536

537Figure 6. Distribution of the major paleocontinents during the Middle Ordovician, showing the 538known geographical distribution of Iocrinus and Merocrinus. Locality markers indicate the 
539presence of a taxon on a palaeocontinent; multiple localities are not noted on a single 540palaeocontinent. Modified from Cocks and Torsvik (2006).

541

542Table 1. Morphological comparison of Iocrinus species.

543

544Table 2. Stratigraphic and geographical distribution of species of Iocrinus and Merocrinus.

545

546

547SUPPLEMENTAL INFORMATION

548Access to supplementary data: http://dx.doi.org/10.5523/bris.uv7qt4c6kpat1befj0937ooml

549Supplemental Data S1. Micro-CT slices, working images, and associated SPIERSedit settings 550file.

551Supplemental Data S2. Interactive 3-D model in VAXML format.

552Figure 1 


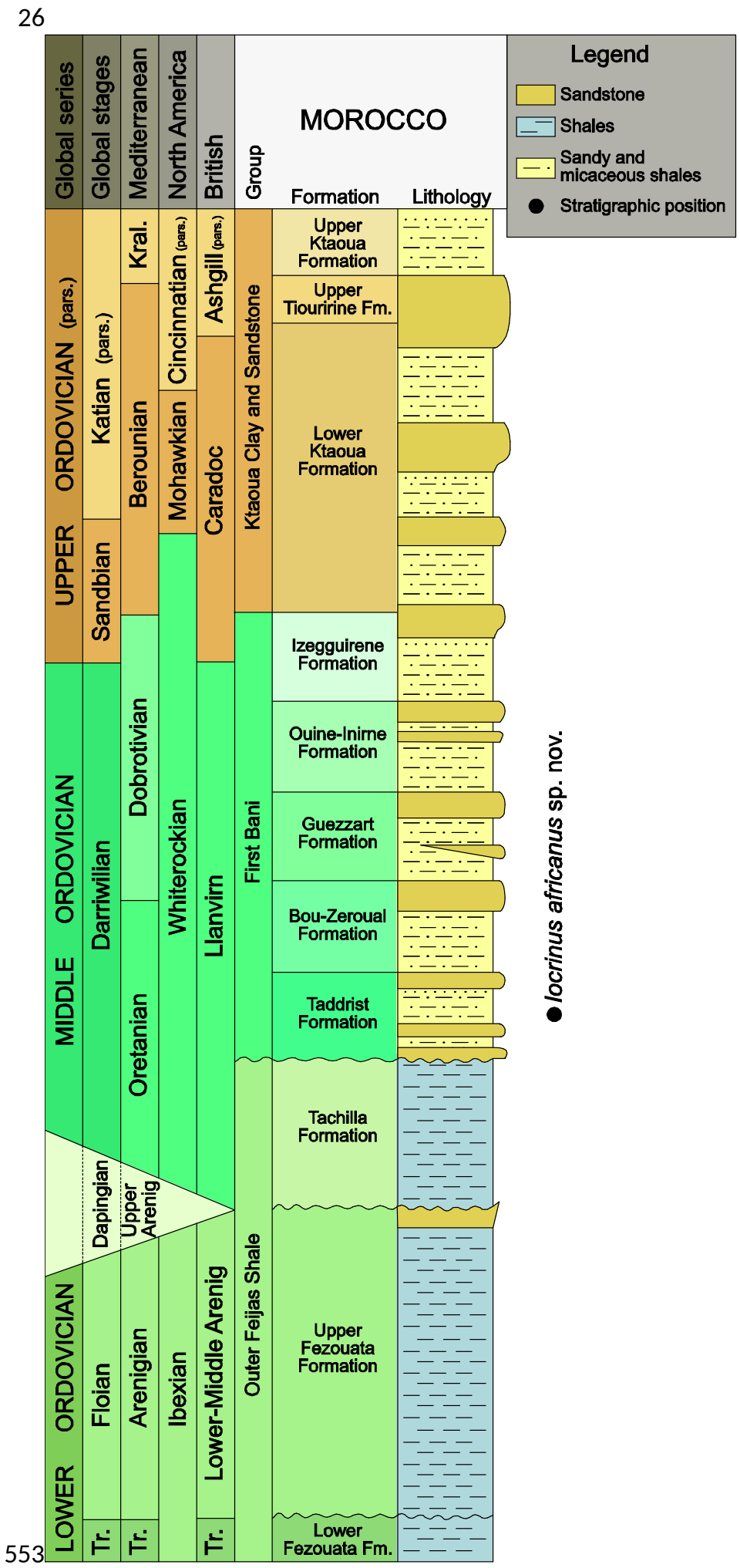

554

555Figure 2 
27

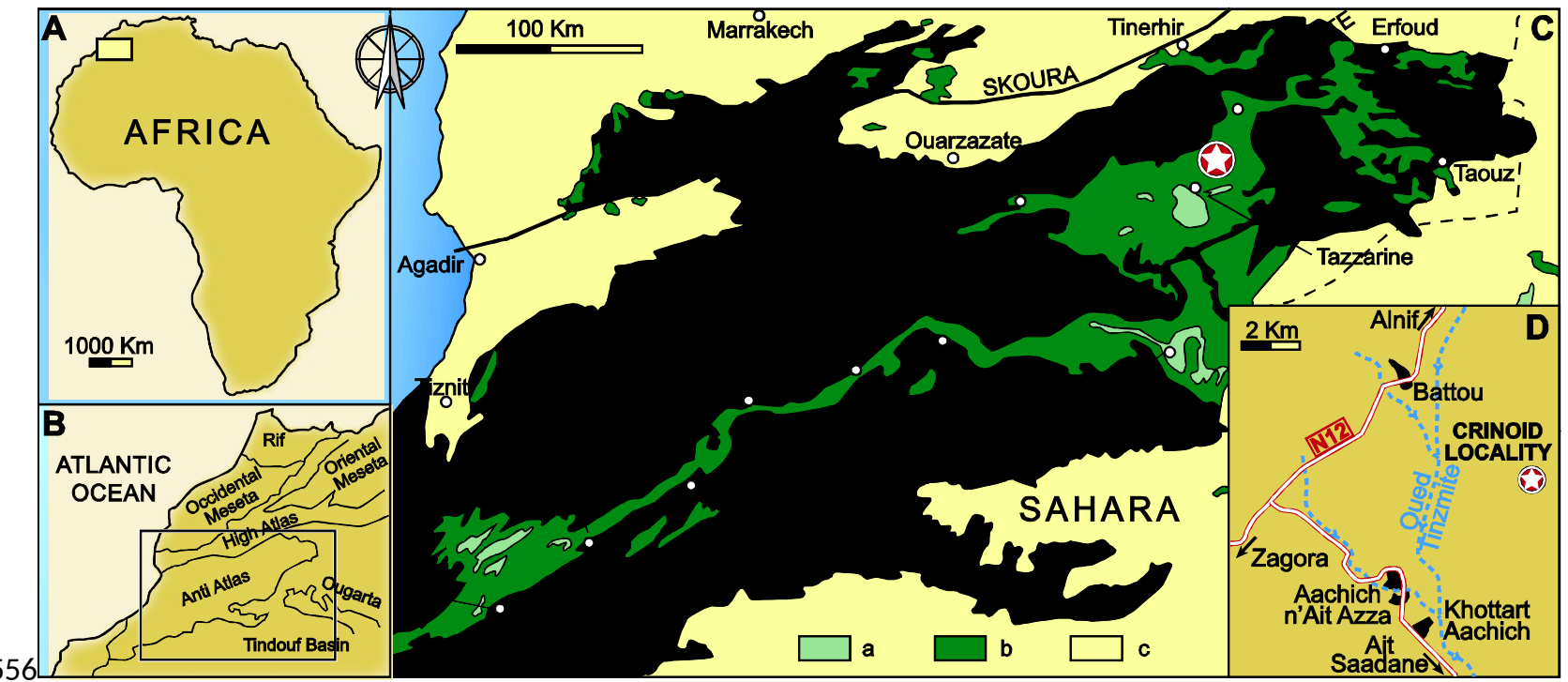

557Figure 3
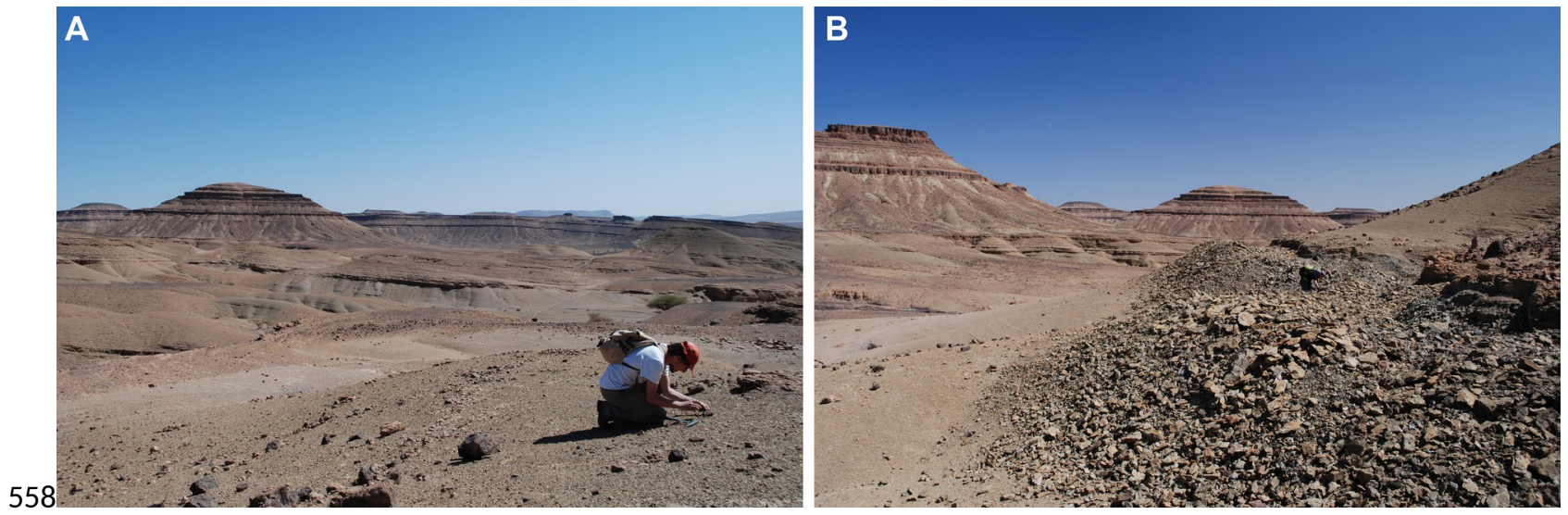

559

560

561

562

563

564

565

566Figure 4 


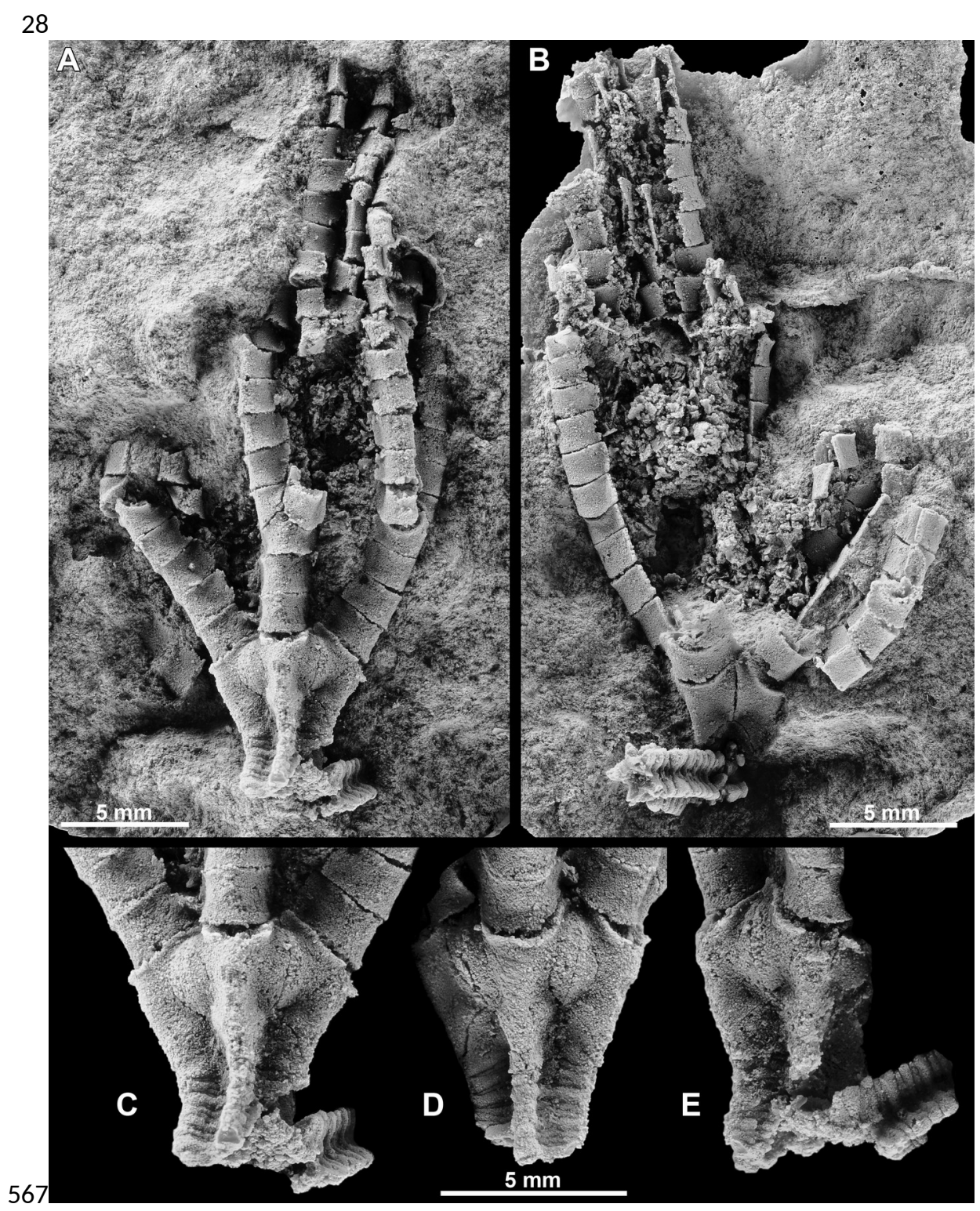

568

569

570

571

572

573

574Figure 5 


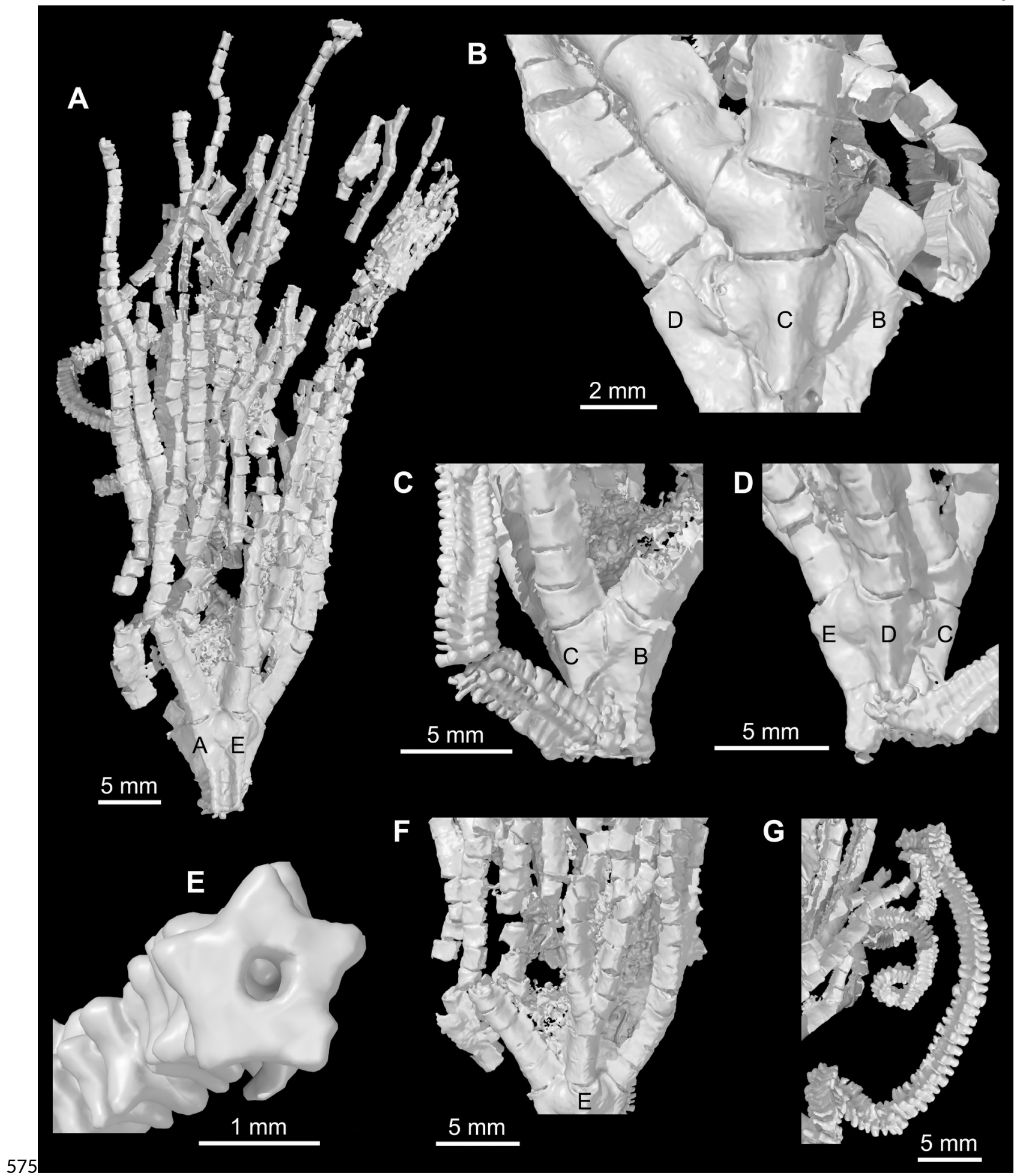

576

577Figure 6 


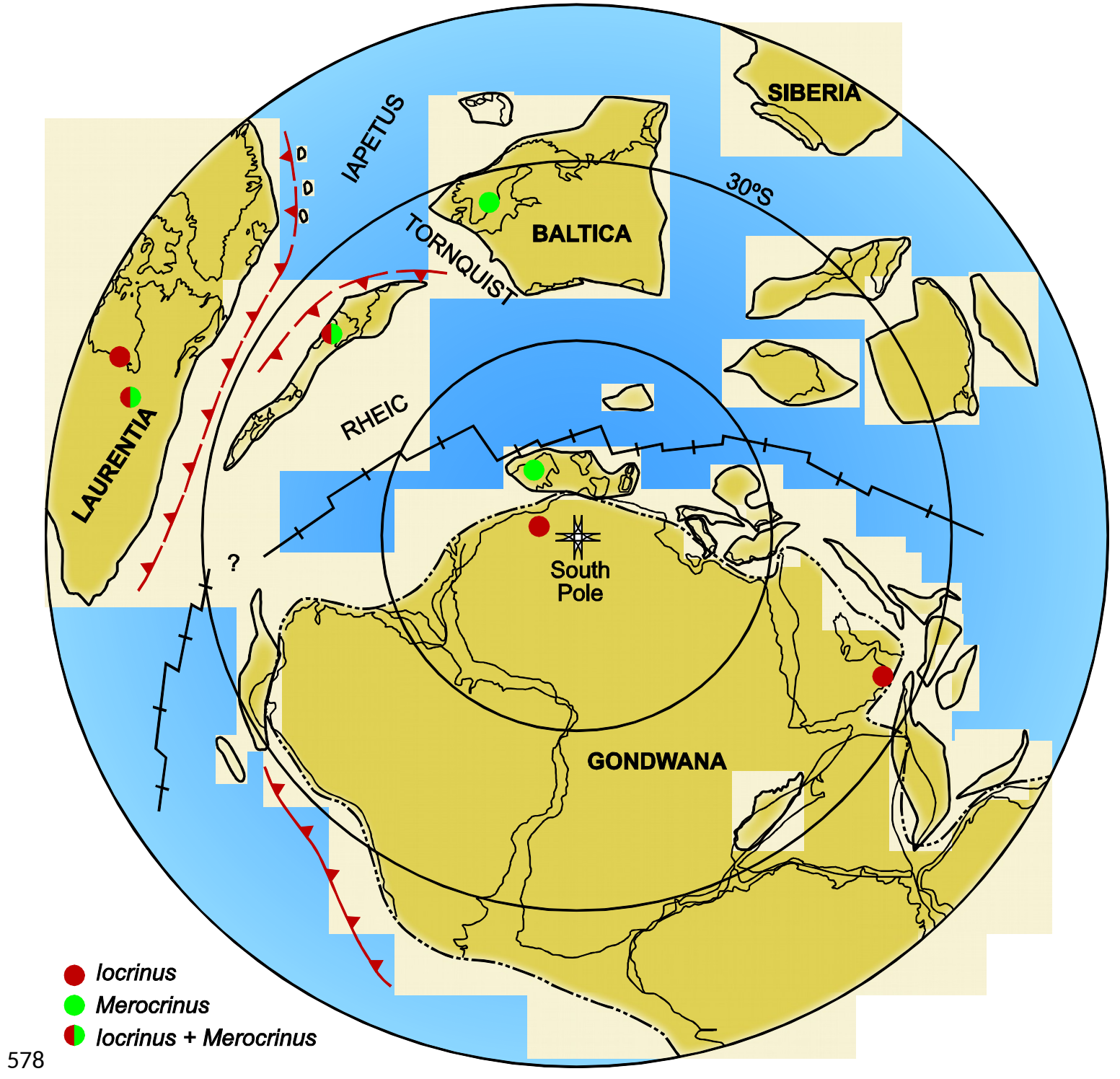

580

581

582

583

584

585Table 1 


\begin{tabular}{|c|c|c|c|c|c|c|c|c|c|c|}
\hline locrinus specles & Basal Plate Height & $\begin{array}{l}\text { Radial Plate Height } \\
\text { vs Width }\end{array}$ & $\begin{array}{l}\text { Transverse Ribbing } \\
\text { on Between } \\
\text { Adjacent Radial } \\
\text { Plates }\end{array}$ & \begin{tabular}{|} 
Primibrachial \\
Shape
\end{tabular} & $\begin{array}{c}\text { Number of } \\
\text { Primibrachials }\end{array}$ & \begin{tabular}{|} 
Number of \\
Secundibrachials
\end{tabular} & $\begin{array}{l}\text { Number of } \\
\text { Tertibrachials }\end{array}$ & $\begin{array}{c}\text { Number of Arm } \\
\text { Bifurcations in } \\
\text { Line }\end{array}$ & $\begin{array}{l}\text { Anal Sac } \\
\text { Plating } \\
\text { Robust }\end{array}$ & $\begin{array}{l}\text { Proximal } \\
\text { Column } \\
\text { Shape }\end{array}$ \\
\hline locrinus crassus & $\begin{array}{l}\text { Approximately } 50 \% \\
\text { of radial plate height }\end{array}$ & $\begin{array}{l}\text { Height approximately } \\
\text { equals width }\end{array}$ & Yes, single, broad & $\begin{array}{l}2.0 \text { times wider } \\
\text { than high }\end{array}$ & 4 to 5 & 4 to 6 & 4 to 8 & As many as 7 & Unknown & Pentastellate \\
\hline $\begin{array}{l}\text { locrinus } \\
\text { llandegleyi }\end{array}$ & $\begin{array}{l}\text { Approximately } 67 \% \\
\text { of radial plate height }\end{array}$ & $\begin{array}{l}\text { Slightly wider than } \\
\text { high }\end{array}$ & No & $\begin{array}{l}2.0 \text { times wider } \\
\text { than high }\end{array}$ & 5 to 8 & 4 to 5 & 4 to 5 & At least 3 & Yes & Pentastellate \\
\hline locrinus pauli & $\begin{array}{l}\text { Approximately } 60 \% \\
\text { of radial plate height }\end{array}$ & $\begin{array}{l}\text { Height approximately } \\
\text { equals width }\end{array}$ & $\begin{array}{l}\text { Yes, double, } \\
\text { narrow }\end{array}$ & $\begin{array}{l}\text { Less than } 2.0 \\
\text { times wder } \\
\text { than high }\end{array}$ & 5 & 5 to 6 & 5 to 8 & 4 & Yes & Pentalobate \\
\hline locrinus similis & Unknown & $\begin{array}{l}\text { Height approximately } \\
\text { equals width }\end{array}$ & Unknown & $\begin{array}{l}1.5 \text { times wider } \\
\text { than high }\end{array}$ & 3 to 4 & Unknown & Unknown & Unknown & Unknown & Unknown \\
\hline $\begin{array}{c}\text { locrinus } \\
\text { subcrassus* }\end{array}$ & $\begin{array}{l}\text { Approximately } 50 \% \\
\text { of radial plate height }\end{array}$ & $\begin{array}{l}\text { Height less than } \\
\text { width }\end{array}$ & Yes, single, narrow & $\begin{array}{l}2.0 \text { times wider } \\
\text { than high }\end{array}$ & 3 to 8 & 4 to 5 & 5 to 13 & $\begin{array}{l}\text { Typically } 4 \text { but } \\
3 \text { to } 8\end{array}$ & Yes & Pentalobate \\
\hline $\begin{array}{c}\text { locrinus } \\
\text { subcrassus } \\
\text { torontoensis }\end{array}$ & $\begin{array}{l}\text { Approximately } 50 \% \\
\text { of radial plate height }\end{array}$ & $\begin{array}{l}\text { Height approximately } \\
\text { equals width }\end{array}$ & Yes, single, narrow & $\begin{array}{c}2.0 \text { times wider } \\
\text { than high }\end{array}$ & 5 & 6 to 7 & 6 to 11 & 4 & Yes & Pentastellate? \\
\hline $\begin{array}{c}\text { locrinus } \\
\text { trentonensis }\end{array}$ & $\begin{array}{l}\text { Approximately } 50 \% \\
\text { of radial plate height }\end{array}$ & $\begin{array}{l}\text { Height approximately } \\
\text { equals width }\end{array}$ & Yes, single, broad & $\begin{array}{l}1.5 \text { times wider } \\
\text { than high }\end{array}$ & 4 to 6 & 6 to 9 & $>12$ & 4 & Yes & Pentalobate? \\
\hline locrinus whitteryi & $\begin{array}{l}\text { Approximately } 67 \% \\
\text { of radial plate height }\end{array}$ & $\begin{array}{l}\text { Slightly wider than } \\
\text { high }\end{array}$ & No & $\begin{array}{l}\text { More than } 2.0 \\
\text { times wider } \\
\text { than high }\end{array}$ & 7 & Unknown & Unknown & Unknown & Yes & Unknown \\
\hline $\begin{array}{l}\text { locrinus africanus } \\
\text { n.sp. }\end{array}$ & $\begin{array}{l}\text { Approximately } 37 \% \\
\text { of radial plate height }\end{array}$ & $\begin{array}{l}\text { 1.25 times higher } \\
\text { than wide }\end{array}$ & Yes, single, broad & $\begin{array}{l}1.5 \text { times wider } \\
\text { than high }\end{array}$ & 3 to 5 & 4 to 5 & 7 to 13 & 3 & No & Pentastellate \\
\hline
\end{tabular}


599Table 2

\begin{tabular}{|c|c|c|c|c|c|c|}
\hline Genus & Species & Formation & Age & Location & Country & $\begin{array}{l}\text { Paleo- } \\
\text { continent }\end{array}$ \\
\hline \multicolumn{7}{|l|}{ IOCRINUS } \\
\hline & $\begin{array}{l}\text { locrinus sp. cf. I. } \\
\text { subcrassus }\end{array}$ & Amdeh Formation & $\begin{array}{l}\text { late } \\
\text { Dapingian or } \\
\text { early } \\
\text { Darriwilian }\end{array}$ & Muscat & Oman & Gondwana \\
\hline & locrinus Ilandegleyi & $\begin{array}{l}\text { Builth Volcanic } \\
\text { Group }\end{array}$ & Darriwillian & Wales & UK & Avalonia \\
\hline & locrinus paufi & $\begin{array}{l}\text { Camnant } \\
\text { Mudstone }\end{array}$ & Darriwillian & Wales & UK & Avalonia \\
\hline & locrinus paufi & $\begin{array}{l}\text { Didmograptus } \\
\text { bifidus Beds }\end{array}$ & Darriwillian & England & UK & Avalonia \\
\hline & Jocrinus sp. cf. pauli & Llandeilo Flags & Darriwillian & Wales & UK & Avalonia \\
\hline & locrinus cf. whitteryi & $\begin{array}{l}\text { volcanic } \\
\text { sandstanes }\end{array}$ & Darriwillian & England & UK & Avalonia \\
\hline & locrinus whitteryi & Chirbury Formation & Sandbian & England & UK & Avalonia \\
\hline & $\begin{array}{l}\text { locrinus cf. } \\
\text { subcrassus }\end{array}$ & Whittery Beds & Sandbian & England & UK & Avalonia \\
\hline & locrinus subcrassus & $\begin{array}{l}\text { Arnheim } \\
\text { Formation }\end{array}$ & Katian & $\begin{array}{l}\text { Southwestern Ohio } \\
\text { Region }\end{array}$ & USA & Laurentia \\
\hline & locrinus subcrassus & Lorraine Shale & Katian & New York & USA & Laurentia \\
\hline & $\begin{array}{l}\text { locrinus cf. } \\
\text { subcrassus }\end{array}$ & Lorraine Shale & Katian & New York & USA & Laurentia \\
\hline & Iocrinus subcrassus & Cobourg Limestone & Katian & Ontario & Canada & Laurentia \\
\hline & Jocrinus subcrassus & $\begin{array}{l}\text { Georgian Bay } \\
\text { Formation }\end{array}$ & Katian & Ontario & Canada & Laurentia \\
\hline & $\begin{array}{l}\text { locrinus subcrassus } \\
\text { torontoensis }\end{array}$ & Dundas Formation & Katian & Ontario & Canada & Laurentia \\
\hline & locrinus similis & Cobourg Limestone & Katian & Ontario & Canada & Laurentia \\
\hline & locrinus subcrassus & $\begin{array}{l}\text { Correyville } \\
\text { Formation }\end{array}$ & Katian & $\begin{array}{l}\text { Southwestern Ohio } \\
\text { Region }\end{array}$ & USA & Laurentia \\
\hline & locrinus sp. & $\begin{array}{l}\text { Fort Atkinson } \\
\text { Formation }\end{array}$ & Katian & Iowa and Illinois & USA & Laurentia \\
\hline & locrinus subcrassus & Fairview Formation & Katian & $\begin{array}{l}\text { Southwestern Ohio } \\
\text { Region }\end{array}$ & USA & Laurentia \\
\hline & locrinus sp. & Kope Formation & Katian & $\begin{array}{l}\text { Southwestern Ohio } \\
\text { Region }\end{array}$ & USA & Laurentia \\
\hline & locrinus subcrassus & Liberty Formation & Katian & $\begin{array}{l}\text { Southwestern Ohio } \\
\text { Region }\end{array}$ & USA & Laurentia \\
\hline & locrinus crassus & Maquoketa Shale & Katian & Illinois & USA & Laurentia \\
\hline & locrinus trentonensis & Rust Formation & Katian & New York & USA & Laurentia \\
\hline & locrinus trentonensis & Trenton Limestone & Katian & New York & USA & Laurentia \\
\hline & locrinus subcrassus & $\begin{array}{l}\text { Waynesville } \\
\text { Formation }\end{array}$ & Katian & $\begin{array}{l}\text { Southwestern Ohio } \\
\text { Region }\end{array}$ & USA & Laurentia \\
\hline \multicolumn{7}{|c|}{ MEROCRINU } \\
\hline & Merocrinus milfanae & Guindo Shales & Darriwilian & $\begin{array}{l}\text { Embabe de } \\
\text { Fresnedas }\end{array}$ & Spain & Gondwana \\
\hline & Merocrinus salopioe & Meadowtown Beds & Darriwilian & & England & Avalonia \\
\hline & $\begin{array}{l}\text { Merocrinus } \\
\text { britonensis }\end{array}$ & Mifflin Formation & Sandbian & Illinois & US & Laurentia \\
\hline & $\begin{array}{l}\text { Merocrinus } \\
\text { britonensis }\end{array}$ & Platteville Group & Sandbian & $\begin{array}{l}\text { Illinois, lowa, } \\
\text { Wisconsin, Minn }\end{array}$ & US & Laurentia \\
\hline & $\begin{array}{l}\text { Merocrinus } \\
\text { impressus }\end{array}$ & $\begin{array}{l}\text { Bromide Formation } \\
\text { (Pooleville Mbr.) }\end{array}$ & Sandbian & Oklahoma & US & Laurentia \\
\hline & $\begin{array}{l}\text { Merocrinus } \\
\text { impressus }\end{array}$ & ? & ? & ? & Sweden & Baltica \\
\hline & Merocrinus curtus & Kope Formation & Katian & $\begin{array}{l}\text { Southwestern Ohio } \\
\text { Region }\end{array}$ & US & Laurentia \\
\hline & Merocrinus curtus & Rust Formation & Katian & New York & US & Laurentia \\
\hline & Merocrinus retractilis & Rust Formation & Katian & New York & US & Laurentia \\
\hline & Merocrinus sp. & $\begin{array}{l}\text { Wisf Formation } \\
\text { (Sinsinewa Mbr.) }\end{array}$ & Katian & Illinois and lowa & US & Laurentia \\
\hline & $\begin{array}{l}\text { Merocrinus } \\
\text { corroboratus }\end{array}$ & Trenton Limestone & Katian & New York & US & Laurentia \\
\hline & Merocrinus typus & Trenton Limestone & Katian & New York & US & Laurentia \\
\hline
\end{tabular}

